\title{
THE TESTIFYING DEFENDANT-A PROPOSED RULE OF LIMITED WAIVER FOR THE TRIAL OF JOINED OFFENSES
}

A defendant in a criminal prosecution who voluntarily testifies at trial waives his fifth amendment privilege against self-incrimination. ${ }^{1}$ Unlike the ordinary witness, the accused cannot be compelled at trial to answer even a single question; but once he has taken the stand and testified in his own behalf, he may be cross-examined like an ordinary witness. ${ }^{2}$ Questions which elicit an inculpatory response are then no longer barred by the fifth amendment privilege, for the defendant's waiver removes the constitutionally prohibited element of compulsion. This waiver rule has been justified on two grounds. The primary rationale is that a defendant should not be allowed to present his side of his own story to the jury without cross-examination designed to discover and correct any distortion of the truth. ${ }^{3}$ A second consideration is that once a defendant has given substantial testimony, he would find little, if any, protection by claiming the privilege. At this point policies of disclosure are thought to outweigh the privilege. ${ }^{4}$

While courts agree that defendant's testimony constitutes a waiver, they disagree upon the precise scope of the waiver. ${ }^{5}$ As a general rule, it extends to those matters properly the subject of cross-examination; ${ }^{8}$ this raises the question what is properly the subject of cross-examination. The majority or federal rule limits cross-examination to matters raised by defendant's testimony in chief, ${ }^{7}$ but it is tempered by an

1 Fitzpatrick v. United States, 178 U.S. 304, 315 (1900) ; C. McCoRMTck, EviDENCE $\$ 131$ (1954); F. Wharton, 3 CRIMINAI EvidENCE $\$ \$ 885-94$ (R. Anderson ed. 1955) [hereinafter cited as WharTon]; J. WIGMORE, 8 Evidence $\$ 2276$ (J. McNaughton rev. ed. 1961) [hereinafter cited as WIGMORE].

For discussions of the accused's right to testify and the prosecutor's right to cross-examine the accused, see Carlson, Cross-Examination of the Accused, 52 Corn. L.Q. 705 (1967); Morgan, The Privilege Against Self-Incrimination, 34 MinN. I. REv. 1 (1949) ; Orfield, Examination of Witnesses in Federal Criminal Cases, 4 ARIz. L. Rev. 215 (1963) ; Popper, History and Development of the Accused's Right to Testify, 1962 WASH. L.Q. 454.

2 Diggs v. United States, 220 F. 545 (9th Cir. 1915), aff'd sub nom., Caminetti v. United States, 242 U.S. 470 (1916); see Johnson v. United States, 318 U.S. 189, 195 (1943) ; Raffel v. United States, 271 U.S. 494 (1926).

3 Foster v. People, 18 Mich. 265, 274 (1869) ; 8 WIGMrore $\$ 2276$, at 457-58 \& n.2.

4 See Rogers v. United States, 340 U.S. 367 (1951) ; Arndstein v. McCarthy, 254 U.S. 71 (1920), decision on remand aff'd, 262 U.S. 355, aff'd on rehearing, 266 U.S. 3 (1924).

5 Professor Wigmore found the cases "in a state of variegated confusion." See 8 WIGMORE $\$ 2276$. Professor Morgan lists 7 different formulations of the permissible scope of cross-examination of the accused. E. Morgan, Basic Problems of Evmence $155-56$ (1954).

6 Fitzpatrick v. United States, 178 U.S. 304, 315 (1900); see E. Griswold, ThE Fifth AMENDMENT Today 22-30 (1957).

7 For a history of the federal rule and an examination of its constitutional basis, see Carlson, Cross Examination of the Accused, supra note 1. Professor Carlson summarizes the arguments favoring a rule limiting cross-examination to matters raised on direct examination: 
exception permitting cross-examination on matters other than those disclosed on direct examination if these subjects are part of a single transaction or chain of events. ${ }^{8}$ The minority rule allows crossexamination to extend beyond matters raised on direct examination to all relevant issues in the case against the accused. ${ }^{9}$ Both rules permit questions on cross-examination concerning other crimes or misconduct not referred to on direct examination for the purpose of impeachment, or disclosure of an established method of operation. ${ }^{10}$ However, there may be little practical difference between these rules, especially if the defendant offers a general denial or alibi and the subject of his testimony is construed as the whole fact of guilt or innocence. ${ }^{11}$

A rule that the defendant's testimony waives his privilege creates special problems when a number of counts are joined for trial. Offenses may be joined if they are of a similar character or if they arise from the same transaction. ${ }^{12}$ If they are tried separately, a defendant's voluntary testimony in one trial does not constitute a waiver of his privilege not to testify at any other trial; ${ }^{13}$ the waiver in the first trial will

(1) Wide-open cross-examination increases the reluctance of the defendant to testify, contrary to the basic rules of evidence which seek to encourage his testimony. (2) It is unfair to permit the prosecutor to establish independent elements in his own case through the vehicle of cross-examination, thereby violating the fundamental concept that the individual should not be conscripted to assist the government in convicting himself. (3) Limited cross-examination subjects any testimony given by the defendant to the antiseptic test of adversary interrogation, yet shields him from overreaching prosecutorial inquisition. (4) The limited rule stimulates governmental investigation from [sic] other sources and discourages forced disclosures by the accused.

Id. $718 \mathrm{n} .46$.

8 Fitzpatrick v. United States, 178 U.S. 304, 314-15 (1900).

- See, e.g., 6 Wrgmore $\$ 1885$. Professor Wigmore found this rule preferable primarily because he disliked the use of the privilege to cut down on the source of information. By his formulation, a defendant's "voluntary offer of testimony upon any fact is a waiver as to all other relevant facts because of the necessary connection between all." 8 WIGMORE $\$ 2276$. It has been suggested that the employment of modern investigatory technology makes use of defendant's self-accusations far less imperative than it might have been when Wigmore wrote. At least, there is no evidence to suggest that the operation of the majority rule has been difficult to administer or inimical to the conduct of successful prosecutions. See Carlson, Cross-Examination of the Accused, supra note 1 , at 718 .

10 See 8 WIGMORE $\$ 2277$; Note, Other Crimes Evidence At Trial: Of Balancing And Other Matters, 70 YaLE L.J. 763 (1961).

118 WIGMORE $\$ 2276$ (d).

12 See, e.g., Fed. R. CrIM. P. 8(a); CAL. Pen. Code Ann. \$954 (Deering 1960).

Counts, which are separate indictable offenses, are joined by the prosecutor in a single indictment, subject to review of the court. De Luca v. United States, 299 F.2d 741,745 (2d Cir. 1924). Consolidation is a judicial procedure by which indictments are brought together for a single trial. Pankratz Lumber Co. v. United States, 50 F.2d 174 (9th Cir. 1931), held that consolidated indictments are in legal effect separate counts of one indictment. Under California law, for example, counts may be joined even though they did not arise out of the same transaction, occur on the same day, or involve the same offenders. People v. McMahon, 116 Cal. App. 2d 883, 254 P.2d 903 (1953). Joinder of distinct offenses in one indictment is permissible where there is a common element of importance in their commission; that element may be either a close similarity between the crimes and their manner of their execution, or the fact that they arose out of a scheme to affect the most serious crime charged. People v. Walker, 112 Cal. App. 2d 462, 246 P.2d 1009 (1952).

13 See, e.g., United States v. Baker, 262 F. Supp. 657, 687 (1966). 
not by itself result in a waiver of the privilege at a subsequent trial. However, this may not be the case when counts are joined; waiver on one may be construed to waive the privilege on all joined counts. This Comment takes the position that the result should not change when the counts are joined for trial. Even though joinder of counts results from an initial judgment that there is some connection among the offenses, ${ }^{14}$ the privilege against self-incrimination should require judicial recognition of a right of limited waiver by which an accused can testify on one or more joined counts, but remain silent on others without incurring the penalty of compelled self-incrimination or adverse comment on his failure to testify. ${ }^{15}$ In People v. Perez, ${ }^{16}$ the California Supreme Court rejected this position and refused to recognize the defendant's right to testify on fewer than all counts joined without incurring these penalties.

\section{A. People v. Perez}

People v. Perez well illustrates the dilemma faced by a defendant in a multiple count indictment. Enrique Perez was tried on four counts of robbery. Count I charged Perez with robbery of a club, count II with robbery of a corner market, and counts III and IV with robbery of a bartender and bar patron. On direct examination Perez offered an alibi with respect to robberies charged in counts I and II but did not explain or deny evidence implicating him in robberies III and IV. On cross-examination, the prosecutor asked Perez a question designed to show that he was with one of the robbers identified in robberies III and IV a few minutes after those robberies. The trial judge sustained defendant's objection to the question on grounds that it went beyond the scope of direct examination.

In closing argument, the prosecution pointed out the defendant's refusal to explain evidence implicating him in robberies III and IV. The trial court instructed the jury that it could draw an adverse inference from the defendant's failure to explain or deny facts within his knowledge. The California Constitution then authorized such com-

14 See note 12 sipra; Wangrow v. United States, 399 F.2d 106 (8th Cir. 1968); Comment, Joint and Single Trials Under Rules 8 and 14 of the Federal Rules of Criminal Procedure, 74 Y ALE L.J. 553 (1965).

15 See Brown v. United States, 356 U.S. 148 (1958) ; Comment, Joinder of Coumts as a Violation of an Accused's Right to Remain Silent, 41 TEMP. L.Q. 458 (1968).

The proposed rule of limited waiver admittedly will not eliminate the adverse inference a jury might draw from defendant's silence. Although testimony on one count accentuates a failure to testify on others, courts have seldom seen such accentuation as raising problems of constitutional dimension. Indeed, the Supreme Court has distinguished for constitutional purposes a jury's inference upon its own initiative and the inference a jury may draw with prosecutorial or judicial prompting. See Griffin v. California, 380 U.S. 609, 614 (1965).

1665 Cal. 2d 615, 422 P.2d 597, 55 Cal. Rptr. 909, cert. granted, 390 U.S. 942, petition for cert. dismissed, 395 U.S. 208 (1969), noted in 41 TEMP. L.Q. 458 (1968). Perez was limited on other grounds in People v. Haston, 69 Cal. $2 \mathrm{~d} 233,250-51.444$ P.2d 91, 102-03, 70 Cal. Rptr. 419, 430-31 (1968). 
ment. ${ }^{17}$ The jury found Perez guilty on all four counts.

Subsequent to the lower court conviction, the United States Supreme Court in Griffin v. California ${ }^{18}$ ruled that California's constitutional provision violated a defendant's privilege against self-incrimination. Griffin applied retroactively to Perez, allowing the defendant to contend on appeal that comment on his refusal to testify on counts III and IV was reversible error. ${ }^{19}$ However, the California Supreme Court affirmed the conviction on all four counts, holding that the court's and the prosecutor's comments on defendant's silence did not violate the privilege against self-incrimination.

The court reasoned that Griffin did not prohibit comment on defendant's failure to testify to the extent the defendant waived his fifth amendment privilege by testifying. They found that defendant's waiver extended beyond counts I and II because, in their view, all four robberies disclosed a common scheme. The court read a statutory provision defining permissible cross-examination ${ }^{20}$ to contain an exception permitting cross-examination on incidents other than those discussed on direct examination if the other incidents disclosed a common plan or modus operandi. ${ }^{21}$ The court thought that cross-examination on

17 CAI. Const. art I, $\$ 13$ (1934) provided:

[B] ut in any criminal case, whether the defendant testifies or not, his failure to explain or to deny by his testimony any evidence or facts in the case against him may be commented upon by the court and by counsel and may be considered by the court or the jury.

At the time the Supreme Court held this provision violated the fifth amendment, 6 states authorized prosecutorial or judicial comment on an accused's failure to testify. Only California and Ohio authorized adverse comment through an explicit constitutional limitation on the privilege against self-incrimination. Griffin v. California, 380 U.S. 609, 611 n.3 (1965).

The fifth amendment prohibition against compulsory self-incrimination was extended to the states by Malloy v. Hogan, 378 U.S. 1 (1964).

18380 U.S. 609 (1965), noted in 70 DrCK. L. REv. 98 (1965); see note 19 infra.

18 O'Connor v. Ohio, 382 U.S. 286 (1965). However, Griffin does not apply retroactively to cases resolved on appeal before its decision date. See Tehan v. United States $e x$ rel. Shott, 382 U.S. 406, 409 n.3 (1965).

20

A defendant in a criminal action or proceeding can not be compelled to be a witness against himself; but if he offers himself as a witness, he may be cross examined by the counsel for the people as to all matters about which he was examined in chief.

Cal. Pen. Code ANN. $\$ 1323$ (Deering 1961). Substantially the same provision now appears in CAL. Ev. Code ANN. $\$ 773$ (West 1966).

21 As a matter of state law, the California Supreme Court had little precedential authority either for recognizing such an exception or for applying it to the Perez situation. California cases generally have required a closer similarity between the crime charged and evidence of other proven offenses which tend to show the accused might have committed the type of crime in question several times. See, e.g., People v. Haston, 69 Cal. 2d 233, 444 P.2d 91, 70 Cal. Rptr. 419 (1968) ; People v. Peete, 28 Cal. 2d 306, 169 P.2d 924 (1946).

Evidence of the accused's criminal history has traditionally been viewed with mistrust. The principal reasons for limiting use of "other crimes" evidence at trial has been the fear that such evidence will prejudice the jury against the accused to such an extent that they may convict either because the accused has been presented as a "bad man" who should be incarcerated regardless of his present guilt or they may infer that because the accused committed one crime, he committed the crime charged. While generally excluding other crimes evidence which proves no more than a criminal disposition, courts have made an exception for evidence of other crimes so closely 
counts III and IV could have produced evidence relevant to the issue of the identity of the perpetrators of all four robberies, and that, contrary to the ruling of the trial court, it should have been permitted. Comment, therefore, did not violate the Griffin rule.

Perez is disturbing in its procedural context because the appellate court put itself in the anomalous position of affirming the verdict on the ground that the trial court erroneously limited the scope of crossexamination. ${ }^{22}$ More disturbing is the fact that the court interpreted the permissible scope of cross-examination to allow the prosecutor to question the defendant concerning alleged offenses for which he was being jointly tried, but on which he wished to remain silent. As a result, a California defendant can now be compelled by joinder of similar offenses to choose between costly alternatives. He must either take the stand and risk cross-examination concerning counts on which he wished to remain silent, or he must sacrifice his right to testify where only facts within his knowledge could acquit him on some counts.

\section{B. The Fifth Amendment Privilege vs. Adversary Interrogation}

The rule of limited waiver proposed by this Comment attempts to reconcile two interests which conflict when the right against selfincrimination is opposed to the right of the prosecutor to cross-examine. The first of these interests is the rationale underlying the fifth amendment. Professor Wigmore, while skeptical of many of the ostensible purposes for the fifth amendment privilege, concedes that a judicially enforceable right of silence rests at least in part on "the prevailing ethic that the individual is sovereign and that proper rules of battle between government and individual require that the individual . . not be conscripted by his opponent to defeat himself." ${ }^{23}$ An accusa-

linked by the type of crime and method of execution that the probative value of such evidence is thought to outweigh the potential prejudice. See Note, Other Crimes Evidence At Trial: Of Balancing and Other Matters, supra note 10. As noted above, California decisions adopting this exception have required a closer correlation between the crimes charged and the "other crimes" offered as evidence than the similarities between the four counts against Enrique Perez.

$A$ second, but not unrelated question, is the admissibility of evidence of the accused's past criminal conduct which did not result in a conviction. In 3 WHARTON $\$ 894$ it is suggested that "the defendant may be cross-examined . . concerning other offenses ... . if the other offense is of the same kind or similar to the one for which he is tried." While it is unclear on the face of the proposition whether "offense" includes evidence of accusations jointly tried, prior acquittals for technical reasons, arrests, or even police suspicions, the authorities cited for the proposition involved only questions of the admissibility of prior convictions. As a corollary to the limited waiver proposal, this Comment adopts the position that "other crimes" evidence should be restricted to evidence of prior convictions, and more specifically, that evidence relating to one count for which an accused is being tried should not be admissible as "other evidence" to establish the guilt of the accused on another count jointly tried. See generally Ladd, Credibility Tests-Current Trends, 89 U. PA. L. Rev. $166(1940)$.

22 See 65 Cal. 2d at 615, 55 Cal. Rptr. at 913, 422 P.2d at 601.

238 WIGMORE §2251. In Culombe v. Connecticut, 367 U.S. 568 (1961), Justice Frankfurter observed that "the State which proposes to convict and punish an individual must produce evidence against him by the independent labor of its officers, not by the simple expedient of forcing it from his own lips." Id. at 582. See also Murphy v. Waterfront Comm'r., 378 U.S. 52, 55-57 (1964). 
torial, as opposed to an inquisitorial, criminal system finds it fundamentally unfair to permit the prosecutor to establish his own case through the forced cooperation of the defendant.

Nevertheless, a defendant should not be allowed to distort the probative value of evidence against him by testifying on selected parts of a single transaction, but remain silent when asked questions which would elicit an inculpatory response. This is the second of the conflicting interests. When the facts of one count do not prove elements of other counts joined for trial, the defendant's testimony on the one count does not distort the probative value of evidence presented against him on other counts. Therefore, his testimony should not be ruled a waiver for any count or counts other than those raised on direct examination. But when counts are joined because they arise from a single transaction or chain of events such that the same facts prove elements of several counts, a defendant testifying on any of these facts should not be permitted to refuse to answer questions on other counts.

\section{A Right of Severance}

Commentators have suggested that where joinder presents this kind of dilemma for the accused, severance as a matter of right provides the only solution. ${ }^{24}$ Justice Peters, dissenting in Peres, noted that if the offenses were separately tried, the defendant could decide in each instance whether to testify or rely upon the privilege against selfincrimination. ${ }^{25}$

Certainly severance is a possible remedy. Under both federal and state rules, trial courts are given broad discretion in passing on defendant's motion for severance. ${ }^{26}$ But courts disagree on whether the prejudice faced by a defendant who wishes to testify on less than all joined counts is the kind of prejudice which merits severance.

In Cross $v$. United States, ${ }^{2 \pi}$ two defendants were jointly indicted for two separate robberies. ${ }^{28}$ Cross wanted to testify on count II but not on count $I$. Following denial of his motion for separate trials, he

24 Comment, Joinder of Counts as a Violation of an Accused's Right to Remain Silent, supra note 15. Construing Griffin to prohibit any activity by the court or prosecutor which serves to direct the jury's attention toward the accused's exercise of his privilege, it is argued that joinder prejudices the accused insofar as it directs the jury's attention to defendant's refusal to testify on some of the joined offenses.

2565 Cal. 2d at 662, 422 P.2d at 601, 55 Cal. Rptr. at 913. Though Justice Peters did not expressly rely on a doctrine of limited waiver, a restrictive view of the permissible scope of cross-examination necessarily underlay his dissent.

26 See, e.g., FED. R. CRTM. P. 14, which authorizes severance if either a defendant or the government is prejudiced by a joinder of offenses. A trial court's decision not to order separate trials is reversible only upon a finding of abuse of its discretion. Wangrow v. United States, 399 F.2d 106, 110 (8th Cir. 1968). See Note, Joint and Single Trials Under Rules 8 and 14, supra note 14.

27335 F.2d 987 (D.C. Cir. 1964).

28 Cross and a codefendant were charged with the robberies of a tourist home and a church rectory. Id. at 989-90. 
testified on both counts. ${ }^{29}$ On appeal, Cross argued that joinder had prejudiced the conduct of his defense because it forced him to testify on count $I$. The Court of Appeals for the District of Columbia implied that defendant's testimony on count II was not a waiver of his privilege on count $I$, but it also recognized that testimony on one of the joined offenses would accentuate a failure to testify on others. Cross was thus coerced into presenting unconvincing and inculpatory testimony on count $I$. Because he could have remained silent at a separate trial on count I without the risk that his silence would make an unfavorable impression on the jury, he had been prejudiced by the joinder to such an extent that failure to grant separate trials was reversible error. ${ }^{\mathbf{3 0}}$

Other courts have not followed Cross. ${ }^{31}$ Indeed, the Court of Appeals for the District of Columbia has retreated somewhat from its position. In Baker $v$. United States, ${ }^{32}$ the court found that there was no need for severance until the defendant "makes a convincing showing that he has both important testimony to give concerning one count and strong need to refrain from testifying on the other." 33 The California Supreme Court faced the same allegation of prejudice in People $v$. Mayen. ${ }^{34}$ After his motion for separate trials was denied, the defendant testified concerning one of the joined offenses and objected to the prosecutor's repeated comment on his failure to deny or explain other charges. On appeal the court recognized the prejudice described in Cross and the trial court's error in permitting the district attorney's adverse comments; however, it affirmed the conviction on the grounds that these were harmless errors in light of what the court considered conclusive evidence of guilt. ${ }^{35}$

Perez, Baker, and Mayen demonstrate substantial judicial reluctance to recognize a broad right to severance whenever a defendant wishes to testify on fewer than all joined offenses. Perhaps the reluctance is well founded, for such a "right" may be administratively impracticable in light of the heavy case loads of today's criminal courts. Assuming that the Cross type of prejudice is not construed as an in-

29 Defendant testified on count II that he was a victim and not a cohort of the robbers who entered the tourist home. His testimony was so convincing that the jury believed Cross despite the prosecution's efforts at cross-examination and impeachment. But on count I his testimony was plainly evasive and unconvincing. The jury convicted Cross of count I but acquitted on count II. Id. at 990 .

$30 \mathrm{Id}$. at 990 ; see note 36 supra.

31 See, e.g., Wangrow v. United States, 399 F.2d 106, 112 (8th Cir.), cert. denied, 393 U.S. 933 (1968).

32 Baker v. United States, 401 F.2d 958 (D.C. Cir. 1968), cert. denied, 394 U.S. 909 (1969) ; cf. Blunt v. United States, 404 F.2d 1283 (D.C. Cir. 1968) (concurrent sentences cured any prejudice against defendant who testified on only certain counts of a multi-count indictment).

33401 F.2d at 977.

34188 Cal. 237, 205 P. 435 (1922).

$35 I d$. at $257-59,205$ P. at $443-44$. 
vasion of the privilege against self-incrimination, ${ }^{36}$ it is unlikely that appellate courts will grant severance in these cases.

\section{E. Limited Waiver}

If a right to severance continues to be unavailable, a rule of limited waiver affords the defendant the best protection against overreaching cross-examination. Limited waiver provides an acceptable accommodation of the defendant's interest in resisting compelled testimony with the state's interest in consolidating indictments for trial.

To implement this rule, it is proposed that the accused, before presenting his case, make a declaration that he intends to testify on certain counts but remain silent on others. Such a declaration would give the court earlier notice of the claimed limitation of waiver than defense counsel's objections to cross-examination on particular counts. More important, the trial court's decision to grant or deny the request would prevent any misconception by either the prosecutor or the defendant concerning the scope of defendant's waiver. The prosecutor would be forbidden from questioning the accused for any purpose concerning the offenses on which he chose to remain silent.

Having set out a rule of limited waiver and procedures for its implementation, it must be admitted that there is virtually no untarnished precedent supporting it. In fact, what little judicial consideration this problem has received appears to argue against such a proposal. But the precedents which state broadly that a defendant's "voluntary offer of testimony upon any fact is a waiver as to all other relevant facts" ${ }^{37}$ have not considered the testimonial waiver in the context of separate and distinct offenses joined for trial. Reexamination of these precedents suggests an exception to the rule of limited waiver formulated above, rather than a rejection of that rule.

Myrick v. United States ${ }^{38}$ is one of the earliest cases to deal with testimonial waiver in the joinder context. Defendant Cunningham was charged with filing two false applications for a publisher's second-class postage rate. The first indictment alleged that Cunningham fraudulently reported commissions paid to agents; the second indictment charged the defendant with falsifying subscription statistics on a second application. After Cunningham had taken the stand and testified regarding the commissions, the district attorney drew the jury's attention to his failure to explain the allegedly exaggerated number of subscribers. Over defense counsel's objection, the trial court ruled

36 Cross ruled only that the dilemma faced by a defendant who sought to testify on fewer than all counts joined was prejudice within the meaning of Rule 14. This kind of prejudice has not been seen as reaching constitutional dimension. In Griffin v. United States, 380 U.S. 609, 614 (1965), Justice Douglas draws a constitutional distinction between what a jury may infer on its own initiative and what the jury may infer when the court calls the jury's attention to defendant's silence and explains that an adverse inference may be drawn.

37 Johnson v. United States, 318 U.S. 189, 195 (1942), citing 8 WIGMORE \$2276(2).

38219 F. 1 (1st Cir. 1915). 
that a defendant in a criminal case could not waive his constitutional protection piecemeal, and that the defendant Cunningham, having taken the stand, and testified as to certain facts in one of the indictments, his failure to testify as to independent facts in that indictment, and as to facts in the other indictment, was the subject of legitimate comment . . . . ${ }^{39}$

The First Circuit reversed, stating:

The question is therefore presented whether a defendant, when set to the bar for trial before a jury upon two indictments charging different offenses, by taking the stand and limiting his testimony to a particular charge in one of the indictments, waives his constitutional right with reference to the charge contained in the other indictment, so that inferences may be drawn against him from his failure to testify as to any of the matters there charged. It seems to us that to state the question is to answer it; that it was not the intention of Congress, in . . . authorizing the trial of an accused person for distinct offenses, at the same time, on two or more indictments, to deprive him of his constitutional right not to have inferences drawn against him by reason of his failure to testify upon one indictment, should he see fit to testify to matters charged in the other indictment; and that this is especially true where the indictments are not consolidated by an order of the court, as they were not in this case, but were tried as independent and distinct matters, though before the same jury. ${ }^{40}$

However, the Supreme Court explicitly disapproved the Myrick analysis in Caminetti v. United States. ${ }^{41}$ Diggs, a defendant in one of three Mann Act appeals joined for argument in Caminetti, was convicted on four joined counts: two counts of transporting two women across state lines for an immoral purpose and two counts of purchasing tickets for the transportation of these women for the proscribed purposes. Diggs testified about events occurring before the trip but contended on appeal that the trial court's adverse comment on his failure to explain events occurring during and after the trip was reversible error. The Ninth Circuit approached the defendant's claim of limited waiver as a matter of statutory construction and ruled that the statute authorizing criminal defendants to testify "should be held to mean that

39 Id. at 9.

40 Id. at 10-11. The court held that because defendant's waiver did not extend to the second indictment, his failure to testify on the crime charged therein was not a legitimate subject of adverse comment by the prosecutor. Id. at 12. See Balliet v. United States, 129 F. 689 (1st Cir. 1904).

41242 U.S. 470, 494 (1917), aff'g inter alia Diggs v. United States, 220 F. 545 (9th Cir. 1915). 
the waiver is complete, and that when it has been made the defendant is no longer under the protection of the amendment." 42 The Supreme Court, noting a "difference of opinion" between the First Circuit opinion in Myrick and the Ninth Circuit's opinion in Diggs v. United States, stated:

We think the better reasoning supports the view sustained in the Court of Appeals in this case, which is that where the accused takes the stand in his own behalf and voluntarily testifies for himself . . . he may not stop short in his testimony by omitting and failing to explain incriminating circumstances and events already in evidence, in which he participated and concerning which he is fully informed, without subjecting his silence to the inferences to be naturally drawn from it.

.. When he took the witness stand in his own behalf he voluntarily relinquished his privilege of silence, and ought not to be heard to speak alone of those things deemed to be for his interest and be silent where he or his counsel regarded it for his interest to remain so, without the fair inference which would naturally spring from his speaking only of those things which would exculpate him and refraining to speak upon matters within his knowledge which might incriminate him. ${ }^{43}$

Nevertheless, Caminetti's disavowal of the Myrick analysis may not in fact be a rejection of a rule of limited waiver. The cases are distinguished by the relationship between the defendant's testimony and the offenses joined for trial. To the extent they are distinguishable, the Supreme Court in Caminetti need not have commented on the Myrick situation in order to affirm the Diggs conviction, and the comments can be considered as dictum. Diggs testified concerning his pretrip relationship with the women he later took across state lines; this testimony had a direct bearing upon all four counts for it tended to rebut the state's allegation of his immoral purpose. Cunningham, on the other hand, testified only about the commissions paid to agents. Excluding considerations of the adverse inference a jury might draw with respect to the subscription fraud count if the defendant's testimony concerning the commission paid to agents had been shown on crossexamination to be false, testimony on the latter charge had no tendency to prove or disprove the indictment for fraudulently misstating the number of subscribers.

This distinction points up an exception which must be made to the limited waiver rule above. The integrity of the fact-finding process 
demands that a defendant be cross-examined about facts other than those disclosed on direct examination if any distortion in the probative value of his disclosure of those facts only can be discovered or corrected by the acquisition of information concerning other facts. ${ }^{44}$ Such distortion occurs most often when the accused testifies about certain elements of a single crime or certain parts of a single transaction or chain of events from which several counts are derived. For example, a robbery defendant's testimony that he came into possession of certain property without any intention to appropriate that property wrongfully seems one-sided and distorted without cross-examination designed to elicit an explanation of defendant's whereabouts at the time of the alleged robbery and his contact with the complainant. In such situations, the defendant's testimony on any element of a crime or any part of a chain of events should constitute a waiver with respect to the entire crime or transaction. Waiver on a count-by-count basis should be permitted only in those situations where the facts disclosed regarding one count do not constitute elements of other joined counts or do not make up part of a single transaction or chain of events.

Johnson v. United States, ${ }^{45}$ the only other case in which the Supreme Court discussed testimonial waiver in a joinder context, is not inconsistent with this exception. Defendant was charged with income tax invasion for the years 1935 through 1937. The prosecution's theory was that Johnson received continuous bribery payments for using his influence to prevent police interference in gambling activities. Defendant testified he received payments through October, 1937, but on cross-examination denied that he received payments during November and December, 1937. He was then asked: "Did you receive any money from numbers in 1938?" The defendant was not on trial for the year 1938 but still could have been indicted. Defendant's counsel objected, arguing that the question went beyond subjects opened by the examination in chief and that it elicited a response that could lead to future prosecution. The trial court permitted Johnson to invoke the fifth amendment, but later allowed adverse comment by the prosecutor on defendant's failure to testify.

The Supreme Court affirmed the conviction, but only after extensive comment on the events in the district court. The Court found that the trial court erroneously sustained defendant's objection to the question concerning the 1938 payments. ${ }^{46}$ The Court thought that the question was within the permissible scope of cross-examination because it tended to show the continuous nature of the transaction in question. The trial court therefore should have denied Johnson's invocation of the privilege. However, the Court went on to say that because the district court granted Johnson's privilege it could not penalize him for

44 See 8 WIGMORE §2278(1).

45318 U.S. 189 (1943) (opinion by Douglas, J.).

46 Id. at 196. 
his silence by allowing adverse comment. Nevertheless, the Supreme Court affirmed the conviction, because Johnson waived his right to raise this error on appeal after the objection to the prosecutor's comment was withdrawn during the trial. ${ }^{47}$

Like Caminetti, the language of Johnson can be read to reject a count-by-count rule of limited waiver; the Supreme Court stated that Johnson could have been compelled to testify concerning the entire transaction, regardless of the number of counts it comprised. However, the central factor in Johnson was the continuous receipt of unreported income, and Johnson testified that this flow was suddenly interrupted. The defendant's testimony concerning 1937 receipts could be tested on cross-examination by eliciting information concerning a later period. It seems reasonable, then, to hold that the defendant's voluntary disclosure of part of a continuous transaction is a waiver which crosses lines drawn between counts based on separate taxable years. Johnson falls within the exception to the proposed standard.

Application of the proposed standard to the four counts in Perez suggests the defendant should not have been penalized for his failure to testify on fewer than all counts joined. Perez's alibi regarding counts I and II should have opened him to cross-examination concerning those counts, but no others. There were no elements of the specific robberies alleged in counts I and II common to those in counts III and IV. Nor were the robberies so similar in mode of execution that they showed a single transaction or chain of events as in Caminetti or Johnson. ${ }^{48}$ Resort need not have been made, therefore, to questions concerning robberies III and IV in order to discover and correct the distortion in defendant's testimony regarding counts I and II. Because Perez's waiver should not have extended to all counts, comment on his failure to testify on counts III and IV violated his fifth amendment privilege.

\section{CONCLUSION}

In a situation in which a defendant wishes to testify on fewer than all counts joined for trial, cross-examination on all counts may directly violate his fifth amendment rights. The defendant who takes the stand may be compelled either to give self-incriminating evidence concerning counts on which he wished to remain silent or to incur adverse comment by the court and prosecutor on his failure to testify.

The doctrine of limited waiver offers an effective alternative to an unqualified right to severance whenever the defendant seeks to testify

47 Id. at 200-01.

$48 \mathrm{On}$ this point the trial court and appellate court disagreed. As noted above, the appellate court ruling may have misinterpreted California precedents. See note 21 supra. The judicial decision that crimes are sufficiently related to permit joinder for trial does not preclude the question whether those crimes are sufficiently related with respect to defendant's testimony that by disclosing facts concerning one count the defendant waives his privilege with respect to all other counts. 
on less than all counts joined. The prosecution may still test the veracity of the defendant's testimony. The accused cannot distort the probative value of his testimony by offering his account of certain facts regarding a given count and then claiming the privilege when crossexamination becomes embarrassing. While juries may in fact draw improper adverse inferences from a defendant's silence, the state should minimize the possibility of such inferences whenever possible. Neither the court nor the prosecutor should be permitted to solemnize the defendant's silence into evidence against him.

Finally, limited waiver would relieve the defendant of the dilemma whether to testify and risk overreaching cross-examination or to remain silent when only facts within his knowledge can acquit him. 